\title{
Üvegszál-erősítésű kompozit fogtömések vizsgálata
}

\section{Examination of Glass-Fibre Reinforced Composite Dental Fillings}

\author{
Borhy Levente, ${ }^{1}$ Farkas Péter Zoltán, ${ }^{2}$ Volom András ${ }^{3}$ \\ ${ }^{1}$ Budapesti Müszaki és Gazdaságtudományi Egyetem, Gépészmérnöki Kar, Anyagtudomány és Technológia \\ Tanszék, Budapest, Magyarország, borhy.levente@edu.bme.hu \\ ${ }^{2}$ Dr. Volom Esztétikai Fogászat, Budapest, Magyarország, farkas.peter013@gmail.com \\ ${ }^{3}$ Dr. Volom Esztétikai Fogászat, Budapest, Magyarország, drvolom@drvolomdental.hu
}

\begin{abstract}
In dentistry, the use of dental fillings is a routine procedure. The use of fillings is a cheap, simple and lowharm dental operation, however, the filling of deep cavities is a difficult task. During this research, three types of fillings were tested: composite fillings bonded directly to the cavity walls, fillings bonded to the cavity walls with a semi-direct method, and composite fillings bonded to the cavity lined with polyethylene fibres. In the course of our examinations, the gaps between the wall of the dental cavity and the dental filling were observed using scanning electron microscopy. The results of these measurements can be used to determine the quality of each type of filling procedure.
\end{abstract}

Keywords: composite dental fillings, microstructural measurements, biomimetics.

\section{Összefoglalás}

A fogászatban ma már mindennapos eljárásnak számít a fogak kompozit töméssel való ellátása. Ez a legtöbb esetben egyszerű és foganyagkímélő (minimálinvazív) beavatkozás, azonban a mély üregek tömése kihívást jelent. Kutatásunk során háromféle töméstípust vizsgáltunk: közvetlenül a fogban polimerizált kompozit tömést, közvetett módon az üregbe ragasztott (ún. semi-direct) tömést, illetve polietilén rosttal erősített kompozit tömést. Vizsgálataink során pásztázó elektronmikroszkóp segítségével figyeltük meg a fogtömés és a betömött üreg falai között keletkező réseket, illetve a résképződés mértékét, ezekből következtetve az egyes töméstípusok minőségére és várható tartósságára.

Kulcsszavak: kompozit fogtömés, mikroszerkezeti vizsgálat, biomimetika.

\section{Bevezetés}

A szájüregi betegségek a becslések szerint körülbelül 3,5 milliárd embert érintenek világszerte. Ezen belül, a WHO adatai szerint a felnőtt népesség közel 100\%-ának van szuvas foga [1]. A szuvas fogak helyreállítása tehát igen lényeges közegészségügyi feladat. A helyreállítás módszertana és anyagtana ennek megfelelően a fogorvostudomány dinamikusan fejlődő területe.

A fog fő állományát, a fog koronájától a foggyökérig a dentin alkotja. A dentin egy kemény, de egyben rugalmas, szerves összetevőkben gazdag szövet, amelyet a koronai részen zománc, a gyökéri részen pedig cement borít. A dentin rugalmas és erős alátámasztást nyújt a sokkal keményebb, ridegebb, szerves összetevőt alig tartalmazó zománcnak [2]. A dentin és a zománc között egy határréteg található, amely erős kötést biztosít a két szövetféleség között [3].

\subsection{Biomimetika}

A biomimetika olyan innovatív, multidiszciplináris megközelítés, amely elsősorban a biológia és müszaki vagy más tudományok együttmüködésén alapul, és célja, hogy biológiai rend- 
szerek modellezésével különféle gyakorlati problémákra dolgozzon ki megoldásokat [4]. A biomimetikus fogászat célja a károsodott fogak egyes szövetféleségeinek helyreállítása anyagok és eljárások olyan kombinációival, amelyekkel az ép, élő foghoz biomechanikai és esztétikai szempontból is leginkább közelítő szerkezet hozható létre [5-7]. A fogászat biomimetikus megközelítésének kiemelt céljai közé tartozik a megmaradt foganyag és a restaurátum (pl. tömés) közötti kötőerő maximalizálása a restaurátum beragasztása során, illetve a fog és a restaurátum által alkotott rendszeren belüli feszültségek csökkentése a tartósság növelése érdekében.

Ami a kötőerőt illeti, ennek legnagyobb elérhető mértéke a ragasztással érintett szövetféleségtől is függ, így különböző módon kell eljárni a zománchoz és a dentinhez való ragasztás során. A kötés létrehozásakor egy úgynevezett hibrid réteg keletkezik, amely a demineralizált (ortofoszforsavval előkezelésként ásványianyag-mentesített) dentin kollagénrostjainak hidrofil gyantával infiltrált, megerősített átmenetet képző rétege. Fontos, hogy a rétegnek bizonyos stabilizációs (a fogorvosi szakirodalomban gyakran: érési) időre van szüksége, különben nem jön létre elég erős kötés, és a későbbiekben ez szétváláshoz és másodlagos szuvasodáshoz vezethet [8, 9].

Amint említettük, a dentin és a zománc ragasztása során eltérő kötőerő érhető el. Ebből az következik, hogy a tömésre használt kompozit fotopolimerizációja során bekövetkező zsugorodás (amennyiben a kompozitot a fogon belül polimerizáljuk) adott esetben ahhoz vezethet, hogy a restaurátum legalább az egyik szövetféleségtől elválik. Ebből érthető, hogy a polimerizációs zsugorodás mérséklése kulcsfontosságú a hosszú távú sikeresség szempontjából [10]. Ennek egy lehetséges módja az üregbeli szálerősítés alkalmazása, ami a zsugorodási feszültség elnyelése útján csökkenti a szétválás kockázatát [11]. Egy másik lehetséges eljárás az ún. szemidirekt vagy közvetett dentinpótlás. Tanulmányunk szempontjából ezzel az eljárással kapcsolatban fontos kiemelni, hogy ennek során a polimerizáció a fogon kívül történik, így a hibrid réteget nem éri közvetlen húzófeszültség, és annak stabilizációjához is bőséges idő áll rendelkezésre [12].

A fogászatban a c-faktor a fogrestauráció során a tömés ragasztott és nem ragasztott felületeinek arányát jelenti. Minél nagyobb ez az érték (tehát minél több a ragasztott felület), annál inkább számolni kell a polimerizáció során fellépő károsodásokkal. Vizsgálatunk során I. osztályú, 5-ös c-faktorú üregeket vizsgáltunk, amelyek a polimerizáció nemkívánatos szerkezeti hatásai szempontjából jelenleg a legnagyobb kihívást jelentik. Ezeket az üregeket általában hagyományos módon, 2-3 rétegben tömik be, ami viszont nagy belső felszültségeket indukál, és akár repedéshez is vezethet [13, 14].

A korszerű szakirodalomban a fogtöméseket mikroszerkezeti és mikroszakító kötésszilárdsági vizsgálatokkal értékelik [15-17], így kutatásunk során olyan innovatív fogtöméseket vizsgálunk, amelyekkel várhatóan kiváltható lehet a fogat borító korona használata több esetben, és lehetséges ezzel a fog természetes részének megőrzése a lehető legnagyobb mértékben.

Célunk az eddig használt fogtöméseknél rugalmasabb, résmentes kapcsolatot létrehozni egy újszerü dentinpótló kompozit anyaggal.

\section{Anyagok és módszerek}

Vizsgálatunk során töméssel restauráltunk I. osztályú üregeket. A restaurálást minden esetben ugyanaz a fogorvos (F. P. Z.) végezte.

\subsection{Anyagok}

Tömőanyagnak EverX Posterior, üvegszál-megerősítésű kompozitot használtunk, amelyet azért fejlesztettek ki, hogy a dentint helyettesítse direkt (közvetlenül a fogban készített), nagy c-faktorú, mély üregek tömése esetén. Üregbeli szálerősítésnek különleges szövésü, Ribbond típusú polietilén rostot használtunk. A pótlás beragasztásához használt kötőanyag minden esetben Kuraray Clearfil SE Protect, kétkomponensű, 6. generációs kötőanyag (ún. önsavazó bond) volt. A tömés fedésére Estelite Asteria Syringe nanokompozitot alkalmaztunk, a közvetett módon (a fogon kívül készített, ún. szemidirekt) tömés fogba való visszahelyezésekor pedig Cosmedent Renamel Microfill folyékony, kompozit tömőanyaggal töltöttük ki a fog és a már polimerizált kompozit tömb közötti teret.

\subsection{A fogrestauráció módszerei}

A vizsgálatokhoz egyébként szerkezetileg ép, megelőzés céljából eltávolított bölcsességfogakat alkalmaztunk. A fogakat a vizsgálat megkezdéséig, illetve annak egyes lépései között 0,5\%-os szobahőmérsékletű Chloramin T oldatban tároltuk a kiszáradás elkerülése érdekében.

A fogtömések előkészítése során a fogakba $4 \times 4 \times 4$ mm-es, I. osztályú mély üreget hoztunk létre fúrással. Ezt követően minden fog esetén a háromféle eljárás egyikét követtük, így kialakítva a három vizsgálati csoportot. 
Az első csoportban EverX kompozittal egy lépésben feltöltött töméseket készítettünk közvetlenül a fogon belül.

A második csoportban a kompozit tömés polimerizálása a fogon kívül történt meg, és a tömést ezt követően ragasztottuk be (indirekt vagy szemidirekt eljárás).

A harmadik csoport sajátossága az volt, hogy kötőanyaggal (adhezívvel) nedvesített polietilén erősítést alkalmaztunk az egylépéses feltöltést megelőzően.

\subsection{Mérési módszerek}

A betömött fogakat a vizsgálatokhoz a következő módon készítettük elő. A fogakat először $20 \mathrm{~mm}$ átmérőjű szilikonhengerekben Duracryl Plus, kétkomponensű műgyantába ágyaztuk be. Térhálósodás után a hengert Buehler IsoMet 1000 gyémánttárcsás vágógéppel 200 1/min fordulaton, a lehetséges legkisebb terhelés mellett hoszszanti irányban elvágtuk, amelyet utána P600, majd P1200 finomságú papírral csiszoltunk, majd ezután $3 \mu \mathrm{m}$-es gyémántszemcsés folyadékkal políroztunk.

Ezekről a mintákról először kisebb nagyítású felvételeket készítettünk Zeiss EVO MA10 pásztázó elektronmikroszkóppal (SEM), 20 kV gyorsítófeszültséggel a tömés és fog közötti rések vizsgálatára, majd nagyobb nagyításban is vizsgáltuk a létrejövő rétegeket. Mivel a gyanta és a fog rossz elektromos vezetők, ezért a felületet vékony aranyréteggel vontuk be a vezetőképesség biztosítására.

\section{Eredmények}

A mikroszkópi képeken (1. ábra) megfigyelhető a tömés és fog között keletkezett esetleges rés, illetve a résképződés mértéke.

Látható, hogy a közvetlenül a kötőanyagra helyezett, EverX típusú dentinpótló anyag a feszültséggyüjtő helyeken, azaz a sarkoknál minimálisan elvált, ami élőben posztoperatív érzékenységet okozhat és szuvasodás alapja lehet.

A nagyobb nagyítású SEM-felvételen megfigyelhető, hogy a külső polimerizálású módszerrel tömött fogak esetén jól elkülöníthetők az egyes rétegek (2. ábra), és itt az egész síkban nem volt megfigyelhető résképződés.

A Ribbond polietilénrosttal erősített fog esetében a minta-előkészítésnél a fog önmagában megrepedt (1. ábra c ), és a tömés sarkainál részleges elválás volt tapasztalható. Ebben a vizsgálatban tehát a polietilénrosttal történő megerősítés nem tudta teljesen megakadályozni a résképződést, bár láthatóan teljesen hatástalan sem volt.
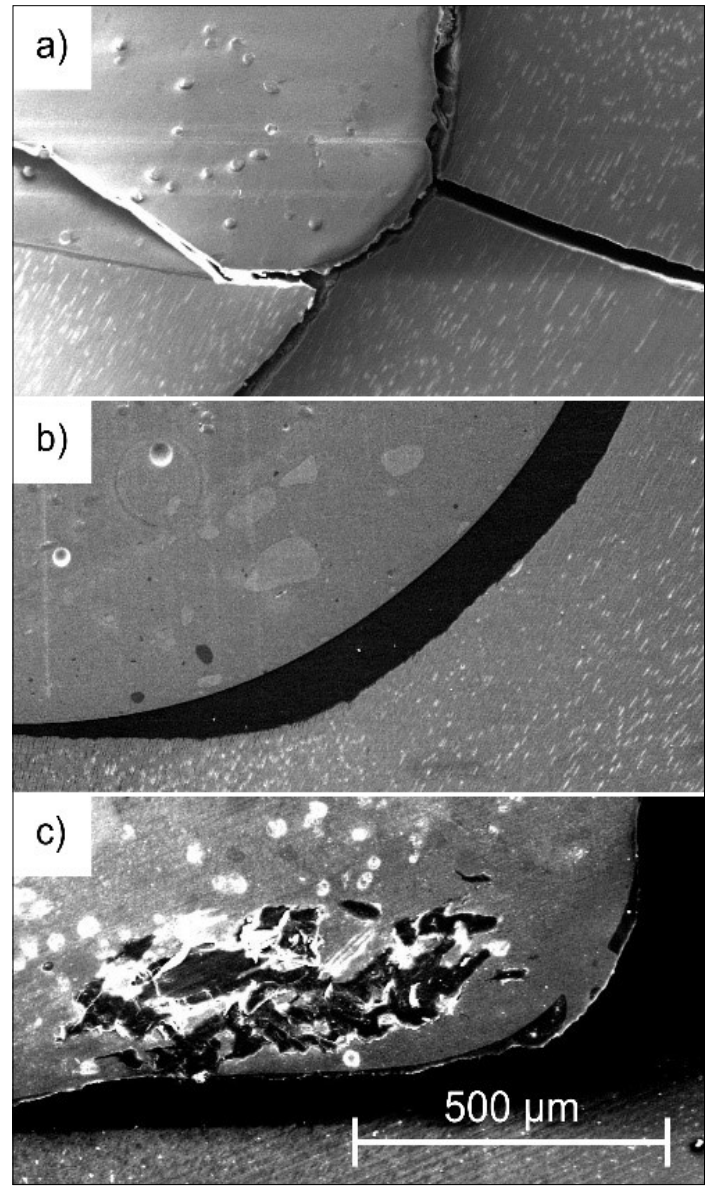

1. ábra. SEM-felvétel a fogon belül polimerizált kompozittal készült (a), a fogon kívül polimerizált és utóbb beragasztott kompozittal készült (b), valamint a Ribbond-szalaggal elökészített (c) tömésekről

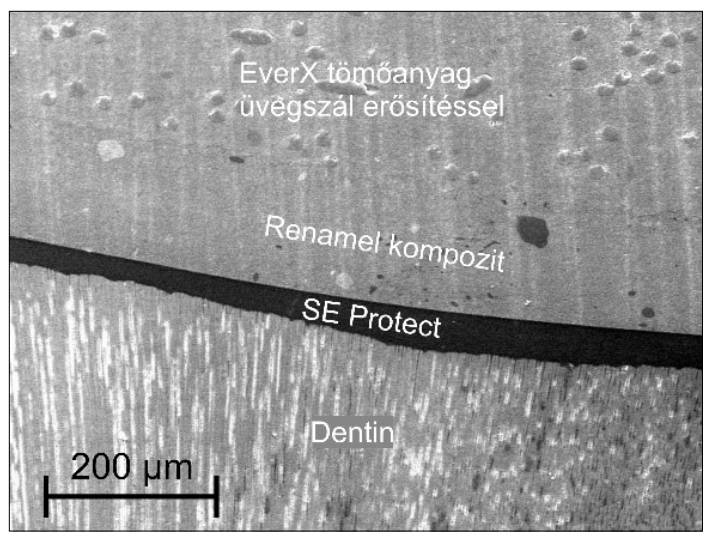

2. ábra. SEM-felvétel a fogon kívül polimerizált kompozitot alkalmazó (közvetett vagy szemidirekt) tömés rétegeiröl 


\section{Következtetések}

Eredményeink szerint jelentős résképződés egyedül a közvetlenül EverX-szel tömött mintán volt tapasztalható. Ennél kisebb mértékű volt az elválás, ha a tömést polietilénrostozattal erősítettük, abban az esetben pedig, ha a kompozit polimerizálása a fogon kívül ment végbe, és csak azt követően ragasztottuk be az üregbe, akkor egyáltalán nem észleltünk résképződést vagy elválást. Meg kell azonban jegyezni, hogy a kis elemszám miatt vizsgálatunk leginkább tájékoztató vizsgálatnak tekinthető, erős következtetések levonására nem alkalmas. Az itt közölt eredmények egyfelől a vizsgálati módszertan alkalmazhatóságát igazolják, másfelől alapot adnak további, számszerűen is értelmezhető vizsgálódásnak.

Vizsgálatainkat a jövőben nagyobb elemszámú mintán a kötésszilárdság vizsgálata irányába is ki kívánjuk terjeszteni, hogy ilyen módon a restaurátumok megfelelőségéről a kvalitatív adatokon felül kvantitatív, statisztikai elemzésre is alkalmas adatokhoz jussunk.

\section{Köszönetnyilvánítás}

A publikáció az Innovációs és Technológiai Minisztérium NTP-SZKOLL-20-0067 kódszámú Nemzeti Tehetség Program pályázatának támogatásával valósult meg. A szerzők köszönetet mondanak dr. Braunitzer Gábornak a kéziratot illető orvosszakmai és közlésmódszertani szempontú észrevételeiért.

\section{Szakirodalmi hivatkozások}

[1] GBD 2017 Disease and Injury Incidence and Prevalence Collaborators.: Global, regional, and national incidence, prevalence, and years lived with disability for 354 diseases and injuries for 195 countries and territories, 1990-2017: a systematic analysis for the Global Burden of Disease Study 2017, The Lancet, 392. (2018) 1789-1858. https://doi.org/10.1016/S0140-6736(18)32279-7

[2] Nanci A.: Chapter 8. Dentin-Pulp Complex. In: Ten Cate's Oral Histology (8. Ed.). Mosby, 2013. 165-204. https://doi.org/10.1016/B978-0-323-07846-7.00008-2

[3] Urabe I., Nakajima S., Sano H., Tagami J.: Physical properties of the dentin-enamel junction region. American Journal of Dentistry, 13. (2000) 129-135.

[4] ISO 18458: Biomimetics - Terminology, concepts and methodology, 2015.

[5] Bazos P., Magne P.: Bio-emulation: biomimetically emulating nature utilizing a histoanatomic approach; structural analysis. The European Journal of Esthetic Dentistry, 6. (2011) 8-19.

[6] Alleman D. S., Nejad M. A., Alleman D. S.: The Protocols of Biomimetic Restorative Dentistry: 2002 to 2017. Inside Dentistry, 13. (2017) 1-6.
[7] Zafar M. S., Amin F., Fareed M. A., Ghabbani H., Riaz S., Khurshid Z., Kumar N.: Biomimetic Aspects of Restorative Dentistry Biomaterials. Biomimetics, 5. (2020) 34 .

https://doi.org/10.1016/B978-0-323-07846-7.00008-2

[8] Kemény A., Hajdu I., Károly D., Pammer D.: Osseointegration specified grit blasting parameters. Materials Today: Proceedings, 5/13. (2018) 26622-26627. https://doi.org/10.1016/j.matpr.2018.08.126

[9] van Meerbeek B., Yoshihara K., van Landuyt K., Yoshida Y., Peumans M.: From buonocore's pioneering acid-etch technique to self-adhering restoratlves. A status perspective of rapidly advancing dentai adheslve technology. The Journal of Adhesive Dentistry, 22. (2020) 7-34.

https://doi.org/10.3290/j.jad.a43994

[10] Yadav R., Kumar M.: Dental restorative composite materials: A review. Journal of Oral Biosciences, 61. (2019) 78-83.

https://doi.org/10.1016/j.job.2019.04.001

[11] Sadr A., Bakhtiari B., Hayashi J., Luong M. N., Chen Y. W., Chyz G., Chan D., Tagami J.: Effects of fiber reinforcement on adaptation and bond strength of a bulk-fill composite in deep preparations. Dental Materials, 36. (2020) 527-534. https://doi.org/10.1016/j.dental.2020.01.007

[12] Jayasooriya P. R., Pereira P. N. R., Nikaido T., Tagami J.: Efficacy of a resin coating on bond strengths of resin cement to dentin. Journal of Esthetic Restorative Dentistry, 15. (2003) 105-113. https://doi.org/10.1111/j.1708-8240.2003.tb00325.x

[13] Nikolaenko S. A., Lohbauer U., Roggendorf M., Petschelt A., Dasch W., Frankenberger R.: Influence of c-factor and layering technique on microtensile bond strength to dentin. Dental Materials, 20. (2004) 579-585.

https://doi.org/10.1016/j.dental.2003.08.001

[14] Sakaguchi R. L., Peters M. C. R. B., Nelson S. R., Douglas W. H., Poort H. W.: Effects of polymerization contraction in composite restorations. Journal of Dentistry, 20. (1992) 178-182.

https://doi.org/10.1016/0300-5712(92)90133-W

[15] Sano H., Chowdhury A. F. M. A., Saikaew P., Matsumoto M., Hoshika S., Yamauti M.: The micro-tensile bond strength test: Its historical background and application to bond testing. Japanese Dental Science Review, 56. (2020) 24-31. https://doi.org/10.1016/j.jdsr.2019.10.001

[16] Magne P., Ubaldini A. L. M.: Thermal and bioactive optimization of a unidose 3-step etchand-rinse dentin adhesive. The Journal of Prosthetic Dentistry, 124 (2020) 487.e1-487.e7. https://doi.org/10.1016/j.prosdent.2020.03.011

[17] Hayashi J., Espigares J., Takagaki T., Shimada Y., Tagami J., Numata T., Chan D., Sadr A.: Real-time in-depth imaging of gap formation in bulk-fill resin composites. Dental Materials, 35. (2019) 585-596. https://doi.org/10.1016/j.dental.2019.01.020 